\title{
FINAL DECLARATION OF THE REGIONAL MEETING FOR ASIA OF THE WORLD CONFERENCE ON HUMAN RIGHTS*
}

\author{
Bangkok, 2 April 1993
}

The Ministers and representatives of Asian States, meeting at Bangkok from 29 March to 2 April 1993, pursuant to General Assembly Resolution 46/116 of 17 December 1991 in the context of preparations for the World Conference on Human rights,

ADOPT this Declaration, to be known as "The Bangkok Declaration", which contains the aspirations and commitments of the Asian region:

\section{Bangkok Declaration}

Emphasizing the significance of the World Conference on Human Rights, which provides an invaluable opportunity to review all aspects of human rights and ensure a just and balanced approach thereto,

Recognizing the contribution that can be made to the World Conference by Asian countries with their diverse and rich cultures and traditions,

Welcoming the increased attention being paid to human rights in the international community,

Reaffirming their commitment to principles contained in the Charter of the United Nations and the Universal Declaration on Human Rights,

Recalling that in the Charter of the United Nations the question of universal observance and promotion of human rights and fundamental freedoms has been rightly placed within the context of international cooperation,

Noting the progress made in the codification of human rights instruments, and in the establishment of international human rights mechanisms, while EXPRESSING CONCERN that these mechanisms relate mainly to one category of rights,

Emphasizing that ratification of international human rights instruments, particularly the International Covenant on Civil and Political Rights and the International Covenant on Economic, Social and Cultural Rights, by all States should be further encouraged,

Reaffirming the principles of respect for national sovereignty, territorial integrity and non-interference in the internal affairs of States,

Stressing the universality, objectivity and non-selectivity of all human rights and the need to avoid the application of double standards in the implementation of human rights and its politicization,

Recognizing that the promotion of human rights should be encouraged by cooperation and consensus, and not through confrontation and the imposition of incompatible values,

Reiterating the interdependence and indivisibility of economic, social, cultural, civil and political rights, and the inherent interrelationship between development,

* A/CONF.157/ASRM/8-A/CONF.157/PC/59 (7 Apr. 1993) 
democracy, universal enjoyment of all human rights, and social justice, which must be addressed in an integrated and balanced manner,

Recalling that the Declaration on the Right to Development has recognized the right to development as a universal and inalienable right and an intergral part of fundamental human rights,

Emphasizing that endeavours to move towards the creation of uniform international human rights norms must go hand in hand with endeavours to work towards a just and fair world economic order,

Convinced that economic and social progress facilitates the growing trend towards democracy and the promotion and protection of human rights,

Stressing the importance of education and training in human rights at the national, regional and international levels and the need for international cooperation aimed at overcoming the lack of public awareness of human rights,

1. Reaffirm their commitment to the principles contained in the Charter of the United Nations and the Universal Declaration on Human Rights as well as the full realization of all human rights throughout the world;

2. Underline the essential need to create favourable conditions for effective enjoyment of human rights at both the national and international levels;

3. Stress the urgent need to democratize the United Nations system, eliminate selectivity and improve procedures and mechanisms in order to strengthen international cooperation, based on principles of equality and mutual respect, and ensure a positive, balanced and non-confrontational approach in addressing and realizing all aspects of human rights;

4. Discourage any attempt to use human rights as a conditionality for extending development assistance;

5. Emphasize the principles of respect for national sovereignty and territorial integrity as well as non-interference in the internal affairs of States, and the non-use of human rights as an instrument of political pressure;

6. Reiterate that all countries, large and small, have the right to determine their political systems, control and freely utilize their resources, and freely pursue their economic, social and cultural development;

7. Stress the universality, objectivity and non-selectivity of all human rights and the need to avoid the application of double standards in the implementation of human rights and its politicization, and that no violation of human rights can be justified;

8. Recognize that while human rights are universal in nature, they must be considered in the context of a dynamic and evolving process of international norm-setting, bearing in mind the significance of national and regional particularities and various historical, cultural and religious backgrounds;

9. Recognize further that States have the primary responsibility for the promotion and protection of human rights through appropriate infrastructure and mechanisms, and also recognize that remedies must be sought and provided primarily through such mechanisms and procedures;

10. Reaffirm the interdependence and indivisibility of economic, social, cultural, civil and political rights, and the need to give equal emphasis to all categories of human rights;

11. Emphasize the importance of guaranteeing the human rights and fundamental 
freedoms of vulnerable groups such as ethnic, national, racial, religious and linguistic minorities, migrant workers, disabled persons, indigenous peoples, refugees and displaced persons;

12. Reiterate that self-determination is a principle of international law and a universal right recognized by the United Nations for peoples under alien or colonial domination and foreign occupation, by virtue of which they can freely determine their political status and freely pursue their economic, social and cultural development, and that its denial constitutes a grave violation of human rights;

13. Stress that the right to self-determination is applicable to peoples under alien or colonial domination and foreign occupation, and should not be used to undermine the territorial integrity, national sovereignty and political independence of States;

14. Express concern over all forms of violation of human rights, including manifestations of racial discrimination, racism, apartheid, colonialism, foreign aggression and occupation, and the establishment of illegal settlements in occupied territories, as well as the recent resurgence of neo-nazism, xenophobia and ethnic cleansing;

15. Underline the need for taking effective international measures in order to guarantee and monitor the implementation of human rights standards and effective and legal protection of people under foreign occupation;

16. Strongly affirm their support for the legitimate struggle of the Palestinian people to restore their national and inalienable rights to self-determination and independence, and demand an immediate end to the grave violations of human rights in the Palestinian, Syrian Golan and other occupied Arab territories including Jerusalem;

17. Reaffirm the right to development, as established in the Declaration on the Right to Development, as a universal and inalienable right and an integral part of fundamental human rights, which must be realized through international cooperation, respect for fundamental human rights, the establishment of a monitoring mechanism and the creation of essential international conditions for the realization of such right;

18. Recognize that the main obstacles to the realization of the right to development lie at the international macroeconomic level, as reflected in the widening gap between the North and the South, the rich and the poor;

19. Affirm that poverty is one of the major obstacles hindering the full enjoyment of human rights;

20. Affirm also the need to develop the right of humankind regarding a clean, safe and healthy environment;

21. Note that terrorism, in all its forms and manifestations, as distinguished from the legitimate struggle of peoples under colonial or alien domination and foreign occupation, has emerged as one of the most dangerous threats to the enjoyment of human rights and democracy, threatening the territorial integrity and security of States and destabilizing legitimately constituted governments, and that it must be unequivocally condemned by the international community;

22. Reaffirm their strong commitment to the promotion and protection of the rights of women through the guarantee of equal participation in the political, social, economic and cultural concerns of society, and the eradication of all forms of discrimination and of gender-based violence against women;

23. Recognize the rights of the child to enjoy special protection and to be afforded the opportunities and facilities to develop physically, mentally, morally, spiritually and 
socially in a healthy and normal manner and in conditions of freedom and dignity;

24. Welcome the important role played by national institutions in the genuine and constructive promotion of human rights, and believe that the conceptualization and eventual establishment of such institutions are best left for the States to decide;

25. Acknowledge the importance of cooperation and dialogue between governments and non-governmental organizations on the basis of shared values as well as mutual respect and understanding in the promotion of human rights, and encourage the nongovernmental organizations in consultative status with the Economic and Social Council to contribute positively to this process in accordance with Council Resolution 1296 (XLIV);

26. Reiterate the need to explore the possibilities of establishing regional arrangements for the promotion and protection of human rights in Asia;

27. Reiterate further the need to explore ways to generate international cooperation and financial support for education and training in the field of human rights at the national level and for the establishment of national infrastructures to promote and protect human rights if requested by States;

28. Emphasize the necessity to rationalize the United Nations human rights mechanism in order to enhance its effectiveness and efficiency and the need to ensure avoidance of the duplication of work that exists between the treaty bodies, the SubCommission on Prevention of Discrimination and Protection of Minorities and the Commission on Human Rights, as well as the need to avoid the multiplicity of parallel mechanisms;

29. Stress the importance of strengthening the United Nations Centre for Human Rights with the necessary resources to enable it to provide a wide range of advisory services and technical assistance programmes in the promotion of human rights to requesting States in a timely and effective manner, as well as to enable it to finance adequetely other activities in the field of human rights authorized by competent bodies;

30. Call for increased representation of the developing countries in the Centre for Human Rights.

\section{INTRA-CHINESE AGREEMENTS*}

\section{Singapore, 29 April 1993}

\section{INTRODUCTORY NOTE}

In 1991 unofficial bodies have been established by the governments on the Chinese mainland as well as on the Island of Taiwan to serve as instruments for mutual contact. The mainland organization is the Association for Relations Across the Taiwan Straits (ARATS) and the one at Taiwan is the Straits Exchange Foundation (SEF).

In 1992 the two chairmen agreed to hold a meeting to discuss matters of mutual concern to both organizations. A first preparatory meeting by representatives was held on 11 April

* Courtesy of Mr. YANG SHENG-Tsung, Taipei 